\title{
Vitamin D deficiency and its effect on respiratory distress syndrome in premature infants: results from a prospective study in a tertiary care centre
}

\author{
Pelin Dogan, Hilal Ozkan, Nilgun Koksal, Onur Bagci, Ipek Guney Varal
}

Uludag University Faculty of Medicine, Department of Pediatrics, Division of Neonatology

\section{Emails}

Pelin Dogan-pelin_akbas@yahoo.com; Hilal Ozkan- hilalozkan@uludag.edu.tr; Nilgun Koksal -nilgunk2008@gmail. com; Onur Bagci - onurbagci@hotmail.com; Ipek Guney Varal - ipekguneyvaral@gmail.com

\begin{abstract}
Background: The positive effects of steroids on lung development are well known, and 1,25-dihydroxy vitamin $\mathrm{D}_{3}$ has been shown to exert positive effects on fetal lung development.

Objective: We aimed to investigate the relationship between 25-hydroxyvitamin D [25(OH)D] levels and respiratory distress syndrome (RDS) in premature infants.

Methods: Infants aged $\leq 32$ gestational weeks who were admitted to the neonatal intensive care unit (NICU) during 1 year were enrolled in this prospective study. $25(\mathrm{OH}) \mathrm{D}$ levels were obtained at the time of admission to NICU. Patients were divided into three groups according to their 25(OH)D levels: severe (group 1), moderate (group 2), and mild (group 3) 25(OH)D deficiencies.

Results: The study comprised 72 patients; of them, RDS was observed in 49 and not observed in 23 patients. The mean $25(\mathrm{OH}) \mathrm{D}$ levels were significantly lower in RDS patients $(\mathrm{p}=0.04)$. Multivariate analysis showed that patients with higher $25(\mathrm{OH}) \mathrm{D}$ levels can be preventive for the development of RDS (odds ratio 0.89; 95\% confidence interval 0.8-0.99; $\mathrm{p}=0.04$ ).

Conclusion: Our study revealed that $25(\mathrm{OH}) \mathrm{D}$ deficiency is an independent risk factor for RDS in premature infants. However, further studies are necessary to explore the association between 25(OH)D deficiency and RDS.

Keywords: 25-hydroxyvitamin D, prematurity, respiratory distress syndrome.

DOI: https://dx.doi.org/10.4314/ahs.v20i1.50

Cite as: Dogan P, Orkan H, Koksal N, Bagci O, Varal IG. Vitamin D deficiency and its effect on respiratory distress syndrome in premature infants: results from a prospective study in a tertiary care centre. Afri Health Sci. 2020;20(1):437-43. bttps:/ / dx.doi.org/ 10.4314/ abs.v20i1.50
\end{abstract}

\section{Introduction}

25-hydroxyvitamin D $[25(\mathrm{OH}) \mathrm{D}]$ is an important steroid hormone involved in bone metabolism and neuromuscular functions; in recent years, an increasing number of reports in the literature have revealed incidences of maternal and neonatal 25(OH)D deficiency. ${ }^{1}$ Management of vitamin $\mathrm{D}$ deficiency is crucial during pregnancy because 25(OH)D deficiency affects fetal development besides

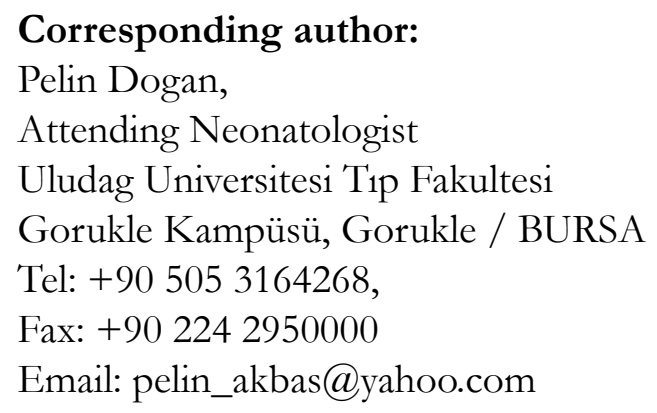

bone metabolism. ${ }^{2} 25(\mathrm{OH}) \mathrm{D}$ exhibits antiproliferative, proapoptotic, and immunomodulatoy properties; additionally, it plays a role in cell development and embryogenesis and helps in fetal lung maturation. ${ }^{3,4}$

Respiratory distress syndrome (RDS) is the most common respiratory problem in premature infants. The critical factors in the pathogenesis of RDS are surfactant deficiency and pulmonary immaturity. ${ }^{5}$ The positive effects of steroids on lung development and maturation are well known, and 1,25-dihydroxy vitamin $\mathrm{D}_{3}\left[1,25(\mathrm{OH})_{2} \mathrm{D}\right]$, which is the active form of $25(\mathrm{OH}) \mathrm{D}$ with steroid structure, has been shown to exert positive effects on fetal lung development. Animal studies have shown $1,25(\mathrm{OH})_{2} \mathrm{D}$ to increase surfactant synthesis and secretion by increasing the number of type 2 alveolar cells. ${ }^{1,6}$ In this study, we aimed to identify the relationship between RDS and $25(\mathrm{OH}) \mathrm{D}$ levels in premature infants. cited. 


\section{Materials and methods}

All preterm infants aged $\leq 32$ gestational weeks admitted to the neonatal intensive care unit (NICU) of the Uludag University Medical School between January 2014 and 2015 were enrolled in this prospective study. Exclusion criteria included refusal of parental consent; infants with major congenital abnormalities, chromosomal anomalies, or cyanotic congenital heart disease; major maternal infection; and chorioamnionitis. The Ethics Committee of the Uludag University Medical Faculty approved this study; a written informed consent was obtained from the parents before enrollment.

RDS diagnosis was established by evaluating $\mathrm{x}$-ray and clinical findings. All patients were treated with nasal continuous positive airway pressure (nCPAP) with $7 \mathrm{~cm}$ $\mathrm{H}_{2} \mathrm{O}$ mean airway pressure. To maintain the arterial oxygen pressure above $60 \mathrm{~mm} \mathrm{Hg}$, the required fraction of inspired oxygen $\left(\mathrm{FiO}_{2}\right)$ was 0.3 for infants aged $\leq 26$ weeks and 0.4 for infants aged $>26$ weeks; the infants who needed $\mathrm{FiO}_{2}$ above 0.4 were treated with "early res-

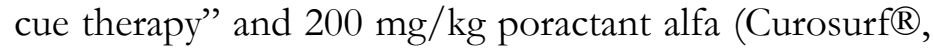
Chiesi Pharmaceuticals, Italy). Infants who did not show clinical improvement during follow-up and needed $\mathrm{FiO}_{2}$ $\geq 0.4$ were administered a second dose $6 \mathrm{~h}$ after the first dose. During the follow-up, up to three doses of surfactant were administered due to RDS. Duration of hospital stay, duration of mechanical ventilation, bronchopulmonar dysplasia (BPD) development, and survival rates were recorded.

Demographic data such as maternal age, education level, socioeconomic status, and maternal disease status were documented. All infants were recorded for gestational age, birth weight, gender, type of delivery, and birth period. Birth seasons were separated into four groups: fall (September, October, November), winter (December, January, February), spring (March, April, May), and summer (June, July, August).

Maternal 25(OH)D usage was classified into three groups: those who never used it during pregnancy, those who used it intermittently ( $<3$ months in total), and those who were regular users ( $\geq 3$ months in total). Patients were divided into three groups according to their $25(\mathrm{OH}) \mathrm{D}$ levels, $<5$ $\mathrm{ng} / \mathrm{mL}$ as severe deficiency group (group 1); 5-15 ng/ $\mathrm{mL}$ as moderate deficiency group (group 2); and 15-30 $\mathrm{ng} / \mathrm{mL}$ as mild deficiency group (group 3). ${ }^{1,7,8}$

Blood samples of patients were obtained in NICU within $6 \mathrm{~h}$ of birth; maternal blood samples were collected within the first $4 \mathrm{~h}$ of birth. Plasma of the blood samples from the infants and mothers were stored at $-80^{\circ} \mathrm{C}$. Samples were analyzed using a Shimadzu LC-20AT high-performance liquid chromatography system (Shimadzu Scientific Instruments, SSI Kyoto, Japan) attached to a UV detector at the Biochemistry Laboratory of the Uludag University Faculty of Medicine (Bursa, Turkey).

\section{Statistical analysis}

Statistical analysis was performed using the Statistical Package for the Social Sciences (SPSS) version 20.0 software (SPSS Inc., Chicago, IL, USA). Besides evaluating the study data for quantitative data comparison using descriptive statistical methods (mean, standard deviation, median, frequency, rate, minimum, and maximum), Student's t-test was used for two-group comparisons of normal distributions, and Mann-Whitney U test was used for two-group comparisons of non-normal distributions. One-way analysis of variance was used to compare three or more groups with a normal distribution. Logistic regression analysis was used to examine the risk factors affecting RDS. Chi-square, Fisher-Freeman-Halton, and Fisher's exact tests were used for comparison of qualitative data. A p value of $<0.05$ was considered significant.

\section{Results}

Of the 72 patients included in the study, RDS was observed in 49 and not observed in 23 patients. The demographic characteristics of the patients with and without RDS are summarized in Table 1. Age in gestational weeks and birth weights of RDS patients were found to be significantly lower than those of the non-RDS patients, whereas the rates of cesarean section $(\mathrm{C} / \mathrm{S})$ and spring-summer births were found to be significantly higher in the former than in the latter (Table 1). 
Table 1: Demographic characterics of the study groups.

\begin{tabular}{|c|c|c|c|}
\hline & $\begin{array}{l}\text { RDS (+) } \\
(n=49)\end{array}$ & $\begin{array}{l}\text { RDS (-) } \\
(n=23)\end{array}$ & $p$ \\
\hline $\begin{array}{l}\text { GA at birth, wk } \\
\text { median (IQR) }\end{array}$ & $29(25-32)$ & $30(26-32)$ & $0.001^{\mathrm{a}}$ \\
\hline $\begin{array}{l}\text { Birth weight, g } \\
\text { Median (IQR) }\end{array}$ & $1020(620-2260)$ & $1400(755-3140)$ & $0.001^{a}$ \\
\hline $\begin{array}{l}\text { Sex, } \mathrm{n}(\%) \\
\text { Male } \\
\text { Female }\end{array}$ & $\begin{array}{l}23(63.9) \\
26(72.2)\end{array}$ & $\begin{array}{l}13(36.1) \\
10(28.8)\end{array}$ & $0.4^{b}$ \\
\hline $\begin{array}{l}\text { Type of delivery, n (\%) } \\
\text { NVD } \\
\text { C/S }\end{array}$ & $\begin{array}{l}1(12.5) \\
48(75)\end{array}$ & $\begin{array}{l}7(87.5) \\
16(25) \\
\end{array}$ & $0.001^{\mathrm{c}}$ \\
\hline $\begin{array}{l}\text { Antenatal steroid: n(\%) } \\
\text { Used } \\
\text { Not used }\end{array}$ & $\begin{array}{l}23(71.9) \\
26(65)\end{array}$ & $\begin{array}{l}7(87.5) \\
16(25)\end{array}$ & $0.6^{b}$ \\
\hline $\begin{array}{l}\text { Season: } \mathrm{n}(\%) \\
\text { Fall } \\
\text { Winter } \\
\text { Spring } \\
\text { Summer }\end{array}$ & $\begin{array}{l}12(50) \\
6(54.5) \\
19(82.6) \\
12(85.7)\end{array}$ & $\begin{array}{l}12(50) \\
5(45.5) \\
4(17.4) \\
2(14.3)\end{array}$ & $0.03^{d}$ \\
\hline
\end{tabular}

${ }^{a}$ Mann-Whitney U test, ${ }^{\text {} C h i ~ S q u a r e ~ t e s t, ~ ' F i c h e r ' s ~ E x a c t ~ t e s t, ~}{ }^{\circ}$ Ficher Freeman Halton test

GA: gestational age; IQR: interquartile range; NVD: normal vaginal delivery; C/S: caesarean section

When the patients were classified according to their vita- tional age, gender, ethnicity, delivery type, and antenatal min D levels, there was no significant difference in terms steroid usage that could be a risk factor for RDS among of perinatal characteristics such as birth weight, gesta- the groups (Table 2).

Table 2: Demographic data in terms of 25(OH)D levels

\begin{tabular}{|c|c|c|c|c|}
\hline & $\begin{array}{c}\text { Group } 1 \\
(\mathrm{n}=29)\end{array}$ & $\begin{array}{c}\text { Group } 2 \\
(n=31)\end{array}$ & $\begin{array}{c}\text { Group 3 } \\
(\mathrm{n}=12)\end{array}$ & $p$ \\
\hline $\begin{array}{l}\text { GA at birth: wk } \\
\text { median (IQR) }\end{array}$ & $29(25-32)$ & $30(26-32)$ & $29(26-32)$ & $0.6^{\mathrm{a}}$ \\
\hline \multicolumn{5}{|l|}{ Sex: n (\%) } \\
\hline Male & $10(27.8)$ & $19(52.8)$ & $7(19.4)$ & \multirow{2}{*}{$0.1^{\mathrm{b}}$} \\
\hline Female & $19(52.8)$ & $12(33.3)$ & $5(13.9)$ & \\
\hline \multicolumn{5}{|l|}{ Type of delivery: } \\
\hline $\begin{array}{l}\mathrm{n}(\%) \\
\text { NVD }\end{array}$ & $2(25)$ & $4(50)$ & $2(25)$ & \multirow[t]{2}{*}{$0.7^{\mathrm{c}}$} \\
\hline $\mathrm{C} / \mathrm{S}$ & $27(42.2)$ & $27(42.2)$ & $10(15.6)$ & \\
\hline \multicolumn{5}{|c|}{$\begin{array}{l}\text { Antenatal Steroid: } \\
\mathrm{n}(\%)\end{array}$} \\
\hline Used & $12(37.5)$ & $14(43.8)$ & $6(18.8)$ & \multirow{2}{*}{$0.9^{b}$} \\
\hline Not used & $17(42.5)$ & $17(42.5)$ & $6(15)$ & \\
\hline
\end{tabular}


25(OH)D levels were $7.2 \mathrm{ng} / \mathrm{mL}$ (median) in the RDS group and $9.7 \mathrm{ng} / \mathrm{mL}$ (median) in the no-RDS group, and there was a significant difference in the levels between the groups ( $\mathrm{p}=0.04)$ (Fig. 1, Table 3). There was no significant association between maternal vitamin D levels and RDS development and it was noteworthy that the rate of
RDS in group 1 (patients with severe 25(OH)D deficiency) was higher (82.8\%) (Table 3). All mothers included in the study were homogeneous regarding their ethnicity/race. All the mothers were Turkish and of white race. There was no significant difference between the RDS and no-RDS groups regarding maternal age, educational status, maternal vitamin use, and disease status.

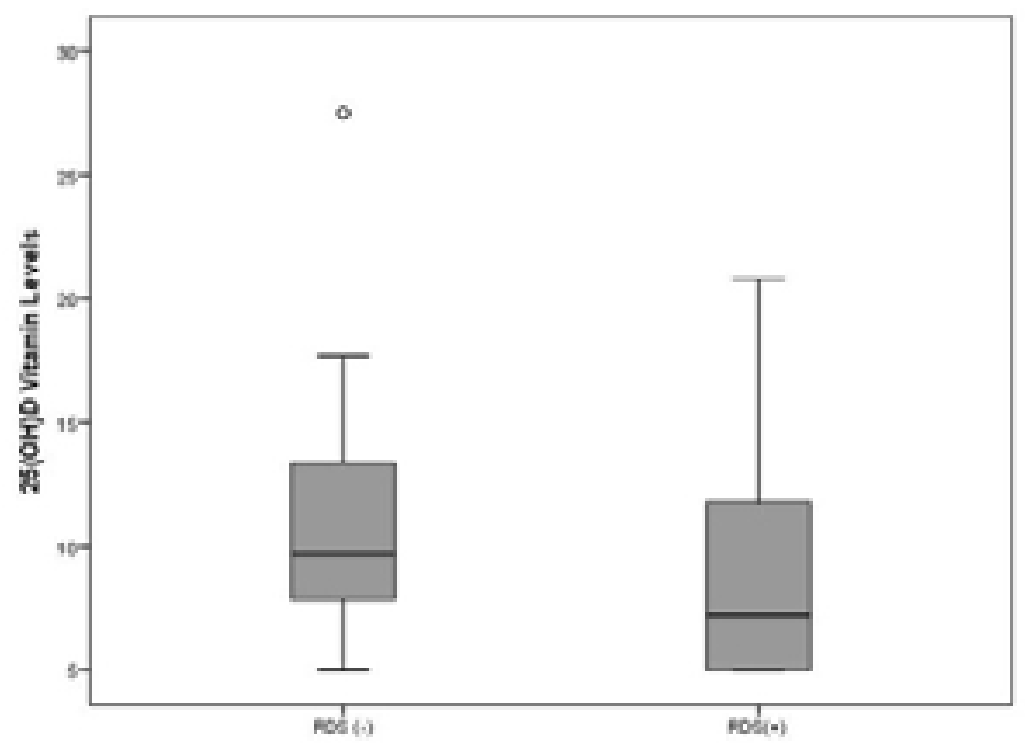

Figure 1: 25(OH)D levels of RDS and no-RDS patients

Table 3: Maternal and infant 25(OH)D levels and RDS ratios of the study groups

\begin{tabular}{|c|c|c|c|}
\hline & $\begin{array}{l}\text { RDS } \\
(\mathrm{n}=49)\end{array}$ & $\begin{array}{c}\text { No-RDS } \\
(\mathrm{n}=23)\end{array}$ & $P$ \\
\hline $\begin{array}{l}\text { Maternal, } 25(\mathrm{OH}) \mathrm{D} \text { level } \\
(\mathrm{ng} / \mathrm{ml}), \\
\text { median (IQR) }\end{array}$ & $11.1(2.6-28.8)$ & $10.2(8-21.9)$ & $0.75^{a}$ \\
\hline $\begin{array}{l}\text { Infant, } 25(\mathrm{OH}) \mathrm{D} \text { level } \\
(\mathrm{ng} / \mathrm{ml}) \\
\text { median (IQR) }\end{array}$ & $7.2(5-20.8)$ & $9.7(5-27.5)$ & $0.04^{a}$ \\
\hline Infant; $\mathrm{n}(\%)$ & & & $0.06^{\mathrm{b}}$ \\
\hline $\begin{array}{l}\text { Group 1 } \\
\text { Group } 2 \\
\text { Group } 3\end{array}$ & $\begin{array}{c}24(82.8) \\
17(54.8) \\
8(66.7)\end{array}$ & $\begin{array}{c}5(17.2) \\
14(45.2) \\
4(33.3)\end{array}$ & \\
\hline
\end{tabular}

'Mann-Whitney U test, ' 'Fisher Freeman Halton Test IQR: interquartile range

Group 1(Severe deficiency): 25(OH)D $\leq 5 \mathrm{ng} / \mathrm{ml}$; Group 2 (Moderete deficiency): 25(OH)D 5-15 ng/ml; Group 3 (Mild deficiency): 25(OH)D 15-30 ng/ml 
When the RDS group was evaluated for the severity of RDS, patients with low vitamin D levels showed a longer duration of mechanical ventilation, which was statistically significant $(p=0.002)$. BPD was not observed in group 3 (mild vitamin D deficiency), whereas BPD rate in group 1 was $45.8 \%(\mathrm{p}=0.3)$.

When the gestational week, antenatal steroid use, and $25(\mathrm{OH}) \mathrm{D}$ levels of the patients were considered as possible independent risk factors in the multiple regression analysis, it was observed that high $25(\mathrm{OH}) \mathrm{D}$ levels of the patients (odds ratio [OR] 0.89; 95\% confidence interval [CI] 0.80-0.99; $\mathrm{p}=0.04)$ and gestational age (OR 0.59; 95\% CI 0.42-0.83; $\mathrm{p}=0.003)$ can be preventive for the development of RDS .

In multivariate analysis, factors that could affect the duration of hospitalization were assessed, and late neonatal sepsis, BPD, and $25(\mathrm{OH}) \mathrm{D}$ levels were included in the model. Of these three factors, BPD was found to have a significant effect on the duration of hospitalization (OR 70.26; 95\% CI 53.4-87.0; $\mathrm{p}<0.001)$.

\section{Discussion}

In this study, we investigated the association between RDS development and vitamin D levels and showed that vitamin $\mathrm{D}$ deficiency is an independent risk factor for RDS development. $25(\mathrm{OH}) \mathrm{D}$ is thought to prevent surfactant insufficiency by increasing the proliferation of type 2 pneumocytes and, thus, increasing surfactant synthesis, a critical factor in RDS pathophysiology ${ }^{9,10}$. Our results are compatible with the recent literature reporting a similar relationship between vitamin $\mathrm{D}$ deficiency and RDS. ${ }^{1,11,12}$ Age in gestational weeks is another important risk factor for RDS besides vitamin D deficiency, and patients with RDS have a lower age in gestational weeks and lower birth weight. ${ }^{5}$ However, even when the cases were controlled according to their age in gestational weeks, vitamin D deficiency was identified as an important risk factor. Moreover, a literature review for RDS risk factors reveals that low birth weight and low $25(\mathrm{OH}) \mathrm{D}$ levels can increase the frequency and severity of RDS. ${ }^{12}$

The active form of $25(\mathrm{OH}) \mathrm{D}$ is known to play an essential role in many tissues and epithelial barriers. ${ }^{13}$ Although there is no clear evidence on the effects of vitamin D on fetal and neonatal lung development, animal studies investigating the effects of vitamin $\mathrm{D}$ and vitamin $\mathrm{D}$ receptors (VDRs) on the development of pulmonary sys- tem have indicated a positive correlation between type 2 pneumocyte and fibroblast proliferation, surfactant synthesis, and VDR upregulation in pulmonary tissue. .,6,14 $^{4}$

Surfactant reduces surface tension and helps in controlling lung inflammation. Many factors regulate surfactant synthesis, including cytokine release, hormones, and growth factors. 6 Corticosteroids induce fetal lung maturation by aiding type 2 pneumocyte differentiation and stimulating surfactant release. ${ }^{4,15}$ Nguyen et al. 9 conducted a study on rats and showed an association between VDR expression and lung maturation level. They stated that $1,25(\mathrm{OH})_{2} \mathrm{D}$ may increase surfactant synthesis through gluconeogenesis and that vitamin D plays a crucial role in epithelial cell-mesenchymal cell interactions during pulmonary system development. Vitamin D increases the production as well as secretion of surfactant-related phospholipids in type 2 pneumocytes; furthermore, it has been reported that during the most active period of alveolarization, $1,25(\mathrm{OH})_{2} \mathrm{D}$ positively affects type 2 pneumocytes and fibroblasts by inhibiting apoptosis and stimulating secretion of surfactant-related phospholipids. ${ }^{16}$ The inhibition of apoptosis results in an increased number of cells postnatally. ${ }^{17,18}$ In a study by Sakurai et al. 14 C-3 epimer, which is a metabolite of $1,25(\mathrm{OH})_{2} \mathrm{D}$, was shown to play a crucial role in antenatal lung maturation, lipofibroblast proliferation, and epithelial mesenchymal interaction mechanisms. In our study, vitamin D levels of the RDS patients were significantly lower similar to the findings in the literature. It is noteworthy that the RDS rate was markedly higher in patients with severe vitamin $\mathrm{D}$ deficiency. ${ }^{11}$

In our study, patients' age in gestational weeks and birth weights were low, as expected, and $\mathrm{C} / \mathrm{S}$ birth rate was high in RDS cases. In a study by Tochie et al. ${ }^{19} \mathrm{C} / \mathrm{S}$ was reported to be an independent predictor for RDS. Regular pregnancy follow-up and avoiding unnecessary early elective $\mathrm{C} / \mathrm{S}$ may reduce the incidence of premature births and RDS.

For patients in group 1, the duration of mechanical ventilation was significantly longer and the BPD rate was $47.1 \%$. Due to the positive effects of high $25(\mathrm{OH}) \mathrm{D}$ levels on lung development, it can be speculated that patients in group 3 had a better prognosis for RDS. The reason behind this speculation is that in group 3, a markedly 
reduced duration of mechanical ventilation was observed and no BPD was observed in any case. A similar observation was recently reported by Cetinkaya et al. ${ }^{20}$ who detected a severe $25(\mathrm{OH}) \mathrm{D}$ deficiency in all premature BPD patients. BPD is one of the most severe morbidities in premature patients, and we found a significant effect of BPD on the duration of hospitalization. In premature infants, positive effects of high $25(\mathrm{OH}) \mathrm{D}$ levels on preventing BPD are promising.

The literature reveals no clarity on the adequate $25(\mathrm{OH})$ $\mathrm{D}$ levels, particularly in premature infants. Fettah et al. ${ }^{11}$ have defined $25(\mathrm{OH}) \mathrm{D}$ deficiency for premature infants as levels $\leq 15 \mathrm{ng} / \mathrm{mL}$. Likewise, in this study, we defined vitamin D levels $<5 \mathrm{ng} / \mathrm{mL}$ as severe deficiency and levels between 5 and $15 \mathrm{ng} / \mathrm{mL}$ as moderate deficiency. In the literature, $25(\mathrm{OH}) \mathrm{D}$ levels $>30 \mathrm{ng} / \mathrm{ml}$ have been accepted as normal. Therefore, we defined levels between 15 and $30 \mathrm{ng} / \mathrm{mL}$ as mild deficiency., ${ }^{8,21,22}$

Multivitamin supplements containing 500 IU of vitamin $\mathrm{D}$ are recommended routinely for all pregnant women in Turkey. In our study, no difference was found between the RDS and non-RDS groups regarding maternal vitamin use. Consistent with previous studies, maternal and neonatal $25(\mathrm{OH}) \mathrm{D}$ vitamin levels were correlated, and both maternal and fetal vitamin D levels were often low. ${ }^{23}$ Although vitamin D supplementation is recommended in pregnancy, both neonatal and maternal vitamin D levels remain low probably due to the lack of regular use of vitamin $\mathrm{D}$ supplements. Also vitamin $\mathrm{D}$ deficiency is more likely to be observed in premature infants aged $<32$ gestational weeks owing to shorter gestation periods and insufficient vitamin D stores. ${ }^{24}$ In our study, infants with severe $25(\mathrm{OH}) \mathrm{D}$ deficiency exhibited higher RDS rates, a longer need for mechanical ventilation, and higher BPD rates. Therefore, vitamin D deficiency at birth may predispose infants to prematurity-related complications.

Our study had several limitations. One of them was the small number of cases in the groups. Furthermore, $25(\mathrm{OH}) \mathrm{D}$ levels were low in all patients; thus, it was unclear whether vitamin $\mathrm{D}$ deficiency was related to prematurity and all prematurity morbidities or only RDS. Additionally, we used common vitamin D deficiency definitions because of the lack of clarity in the literature regarding normal $25(\mathrm{OH}) \mathrm{D}$ vitamin levels corresponding to gestational weeks. Nonetheless, we believe that largescale studies on $25(\mathrm{OH}) \mathrm{D}$ vitamin levels according to gestational weeks are needed.

\section{Conclusion}

$25(\mathrm{OH}) \mathrm{D}$ deficiency is an independent risk factor for RDS development in premature infants, and high neonatal $25(\mathrm{OH}) \mathrm{D}$ levels at birth may protect premature infants against RDS. However, further studies with more patients are necessary to assess the association between 25(OH)D deficiency and RDS.

\section{Conflict of interest}

None.

\section{Funding}

None.

\section{References}

1. Fettah ND, Zenciroğlu A, Dilli D, Beken S, Okumuş $\mathrm{N}$. Is higher 25-hydroxyvitamin $\mathrm{D}$ level preventive for respiratory distress syndrome in preterm infants? $A m \mathrm{~J}$ Perinatol 2015. 32(3): p. 247-50.

2. Thandrayen K, Pettifor JM. Maternal vitamin D status: implications for the development of infantile nutritional rickets. Rheum Dis Clin North Am 2012. 38(1): p. 61-79.

3. Thacher TD, Clarke BL. Vitamin D insufficiency. Mayo Clin Proc 2011. 86(1): p. 50-60.

4. Lykkedegn S, Sorensen GL, Beck-Nielsen SS, Christesen HT. The impact of vitamin D on fetal and neonatal lung maturation. A systematic review. Am J Physiol Lung Cell Mol Physiol 2015. 308(7): p. L587-602.

5. Rodriguez RJ. Management of respiratory distress syndrome: an update. Respir Care 2003. 48(3): p. 279-86; discussion 286-7.

6. Phokela SS, Peleg S, Moya FR, Alcorn JL. Regulation of human pulmonary surfactant protein gene expression by 1alpha, 25-dihydroxyvitamin $\mathrm{D}_{3}$. Am J Physiol Lung Cell Mol Physiol 2005. 289(4): p. L617-26.

7. Misra M, Pacaud D, Petryk A, Collett-Solberg PF, Kappy M; Drug and Therapeutics Committee of the Lawson Wilkins Pediatric Endocrine Society. Vitamin D deficiency in children and its management: review of current knowledge and recommendations. Pediatrics 2008. 122(2): p. 398-417.

8. Holick MF, Binkley NC, Bischoff-Ferrari HA, Gordon CM, Hanley DA, Heaney RP, et al; Endocrine Society. 
Evaluation, treatment, and prevention of vitamin D deficiency: an Endocrine Society clinical practice guideline. $J$ Clin Endocrinol Metab 2011. 96(7): p. 1911-30.

9. Nguyen M, Trubert CL, Rizk-Rabin M, Rehan VK, Besançon F, Cayre YE, et al. 1,25-Dihydroxyvitamin D3 and fetal lung maturation: immunogold detection of VDR expression in pneumocytes type II cells and effect on fructose 1,6 bisphosphatase. J Steroid Biochem Mol Biol 2004. 89-90(1-5): p. 93-7.

10. Ballard PL, Ertsey R, Gonzales LW, Gonzales J. Transcriptional regulation of human pulmonary surfactant proteins SP-B and SP-C by glucocorticoids. Am J Respir Cell Mol Biol 1996. 14(6): p. 599-607.

11. Yu RQ, Chen DZ, Hao XQ, Jiang SH, Fang GD, Zhou Q. Relationship between serum 25(OH)D levels at birth and respiratory distress syndrome in preterm infants. Zhongguo Dang Dai Er Ke Za Zhi 2017. 19(11): p. 1134-1137.

12. Kazzi SNJ, Karnati S, Puthuraya S, Thomas R. Vitamin D deficiency and respiratory morbidity among African American very low birth weight infants. Early Hum Dev 2018. 119: p. 19-24.

13. Kong J, Zhang Z, Musch MW, Ning G, Sun J, Hart J, et al. Novel role of the vitamin $\mathrm{D}$ receptor in maintaining the integrity of the intestinal mucosal barrier. Am J Physiol Gastrointest Liver Physiol 2008. 294(1): p. G208-16.

14. Sakurai R, Shin E, Fonseca S, Sakurai T, Litonjua AA, Weiss ST, et al. 1alpha,25(OH)2D3 and its 3-epimer promote rat lung alveolar epithelial-mesenchymal interactions and inhibit lipofibroblast apoptosis. Am J Physiol Lung Cell Mol Physiol 2009. 297(3): p. L496-505.

15. Di Renzo GC, Anceschi MM, Cosmi EV. Lung surfactant enhancement in utero. Eur J Obstet Gynecol Reprod Biol 1989. 32(1): p. 1-11.
16. Lee P, Nair P, Eisman JA, Center JR. Vitamin D deficiency in critically ill patients. N Engl J Med 2009. 360(18): p. 1912-4.

17. Hansdottir S, Monick MM, Hinde SL, Lovan N, Look DC, Hunninghake GW. Respiratory epithelial cells convert inactive vitamin $\mathrm{D}$ to its active form: potential effects on host defense. J Immunol 2008. 181(10): p. 7090-9.

18. Barnett N, Zhao Z, Koyama T, Janz DR, Wang CY, May AK, et al. Vitamin D deficiency and risk of acute lung injury in severe sepsis and severe trauma: a case-control study. Ann Intensive Care, 2014. 4(1): p. 5.

19. Tochie JN, Choukem SP, Langmia RN, Barla E, Koki-Ndombo P. Neonatal respiratory distress in a reference neonatal unit in Cameroon: an analysis of prevalence, predictors, etiologies and outcomes. Pan Afr Med J 2016. 24: p. 152.

20. Çetinkaya M, Çekmez F, Erener-Ercan T, Buyukkale G, Demirhan A, Aydemir G, et al. Maternal/neonatal vitamin D deficiency: a risk factor for bronchopulmonary dysplasia in preterms? J Perinatol 2015. 35(10): p. 813-7. 21. Mulligan ML, Felton SK, Riek AE, Bernal-Mizrachi C. Implications of vitamin D deficiency in pregnancy and lactation. Am J Obstet Gynecol 2010. 202(5): p. 429 e1-9. 22. Cizmeci MN, Kanburoglu MK, Akelma AZ, Ayyildiz A, Kutukoglu I, Malli DD, et al. Cord-blood 25-hydroxyvitamin D levels and risk of early-onset neonatal sepsis: a case-control study from a tertiary care center in Turkey. Eur J Pediatr 2015. 174(6): p. 809-15.

23. Hollis BW, Wagner CL. Assessment of dietary vitamin $\mathrm{D}$ requirements during pregnancy and lactation. $A m$ J Clin Nutr 2004. 79(5): p. 717-26.

24. Marshall I, Mehta R, Petrova A. Vitamin D in the maternal-fetal-neonatal interface: clinical implications and requirements for supplementation. J Matern Fetal Neonatal Med 2013. 26(7): p. 633-8. 